Winfried Ruigrok

\title{
From Niche to Mass Markets: Rival Strategies in Promoting Fair Trade Organic Commodity Chains
}

\begin{abstract}
This article examines rival strategies employed by public, private and civil society actors to promote fair trade organic commodity chains. The article analyses the case of fair trade organic cotton as a produce that is on the brink of reaching a mass market, and compares this with patterns of the more widely documented fair trade organic fruit case. It is shown how variations in commodity chain configurations and interfaces reflect different stakeholder positions and interests, as well as development philosophies. The case of fair trade organic cotton chains illustrates how stakeholder involvement may speed up learning and thus facilitate mass-market entry. Finally, it is argued that rival commodity chain configurations make it difficult to agree upon common fair trade organic cotton certification strategies.
\end{abstract}

\section{Introduction}

Markets for 'ethical consumer products' (Crane 2001) have experienced buoyant growth rates over the past decade. Consumers appear increasingly prepared to pay more for ethical products ranging from food to sports gear that meet strict and credible social and/or environmental standards (Didier/Lucie 2008; Mahé 2010). Thus, encouraged by non-governmental organisations (NGOs), governments and private sector actors, farmers across the globe have stepped up efforts to grow fair trade labelled and organic produce such as bananas, mangos and cotton.

Inevitably, growing demand for fair trade organic products poses new challenges. Most importantly, there is not one clear trajectory as to how to manage the transformation 'from niche to mass market' (Meier 2004). For instance, the distinct stages of many agricultural commodities chains are globally dispersed. Due to differences between and complexities of international commodity chains, there are a variety of emerging strategies, commodity chain structures and competing business models aiming for the 'ethical market'. This article seeks to unravel these differences and complexities by looking at systematic features such as the type of commodity, notions of fair trade or sustainability, and the type of actors involved, in order to assess future trajectories to promote fair trade organic products. 
In addition, the success of ethical consumer products raises questions of labelling strategies and certification. There are three interrelated challenges here. First, fair trade products are not necessarily produced organically, and organic products do not necessarily classify as fair trade goods. The purpose of promoting fair trade labelled products is to contribute to poverty alleviation in developing countries and to greater equity in international trade. On the other hand, organic farming, which excludes the use of synthetic inputs such as synthetic fertilizers and pesticides, may take place in developing as well as developed countries. To mass-market consumers this distinction may not be immediately obvious. Second, a wide variety of certification institutions has emerged which may be difficult to tell apart. These institutions have typically adopted their own (though not always transparent) certification guidelines and practices in order to persuade potential consumers that some kind of social and/or environmental monitoring has taken place. Third, media reports have suggested that in some cases fair trade auditing procedures may have been faulty (Financial Times, 9 September 2006). These developments suggest that consumers are increasingly confronted with confusing signals, which may undermine the fragile trust massmarket consumers are starting to put into 'ethical products' (Mahé 2010). Thus, the second purpose of this article is to identify how certification practices are associated with specific commodity chain configurations, in order to establish whether or how certification may be consistent, encompassing and credible.

This article addresses these questions by examining the case of fair trade and organic cotton, and by analysing what commodity chain configurations best facilitate the transformation from niche to mass market. Albeit still low in absolute numbers, the production of fair organic cotton has risen sharply, especially after large retailers such as Wal-Mart and M\&S have started to market organic cotton-based products. To firms facing cutthroat competition and under siege for e.g. unethical recruiting behaviours, adding fair organic cotton-based goods to their product range at affordable prices represents an opportunity to generate a more favourable image and boost margins. At the same time, large firms owning strong consumer brands and seeking to position themselves as ethical companies face the choice to join established certification efforts or set up rival 'fair' or 'organic' labels. In this article we argue that this decision depends at least partly on configurations and interests currently emerging along the fair organic cotton commodity chains. Thus, this article fits in the 'political' as well as 'integrative' approaches within the business ethics literature (Garriga/Melé 2004) and extends work linking e.g. commodity chain coordination mechanisms and labelling (Ims/Jakobsen 2006).

The article is organised as follows. Section 2 critically reviews the literature on fair trade, international commodity chains and labelling/certification, and identifies unresolved issues. Section 3 sketches trends in the market for organic cotton, while the section 4 explains the method of this study. The subsequent sections present the results in two steps, first by comparing international cotton chains and international fruit chains, and second by presenting three empirically observable, distinct models of promoting fair organic cotton. The article concludes by suggesting strategies to overcome current challenges. 


\section{Theoretical Framework}

The academic literature examining how the private, public and civil society sector does, could or should develop sustainable and fair international commodity chains is partial in both senses of the word. First, authors usually discuss only one or two aspects of this broad question, e.g. the concept of sustainability or fair trade, the appropriate role of stakeholders, or the shape and dynamics of international commodity chains. Second, some authors have been led by allegiance rather than rigour of analysis, e.g. postulating rather than analysing the positive effects of fair trade, or declaring rather than examining claims that successful commodity chain development requires full stakeholder inclusion. Below we review the literature on fair trade, commodity chains and certification.

\subsection{Fair Trade}

The economics and management literature on fair trade has emerged relatively recently. Trade economists have used the label 'fair trade' primarily to discuss the pros and cons of trade protection and examine whether and how developed nations or specific regions within developed nations had been or could be damaged by trade liberalisation. International economics scholars promoting the notion of (ethical) fair trade have often failed to define this concept (e.g. Stiglitz/Charlton 2005). Interestingly, some recent studies have started to question the effects of fair trade on the incomes of farmers in developing economies, or on the development prospects of developing nations (Griffiths 2011; Valkila 2009).

Likewise, the topic of fair trade has not been discussed elaborately in internationally leading management journals. Most studies have supported the notion of fair trade (e.g. Hira/Ferrie 2006). Scholars have investigated e.g. marketing aspects of fair trade products (Didier/Lucie 2008; Porret/Chambol 2007), the extent to which fair trade labels help raise consumer awareness (Loureiro/Lotade 2005 ) or the evolution of fair trade organisations (Huybrechts 2010). In addition there is a descriptive literature narrating efforts to establish fair trade published e.g. in edited volumes aimed primarily at a community already interested in the topic (e.g. Meier 2004).

Fair Trade has been defined as follows:

"Fair Trade is a trading partnership, based on dialogue, transparency and respect, that seeks greater equity in international trade. It contributes to sustainable development by offering better trading conditions to, and securing the rights of, marginalised producers and workers - especially in the South. Fair Trade organisations (backed by consumers) are engaged actively in supporting producers, awareness raising and in campaigning for changes in the rules and practice of conventional international trade." (European Fair Trade Association 2011)

This definition contains three components which we discuss below. 
(i) Sustainability. A core objective of fair trade is to contribute to sustainable development in the South. The Brundtland Commission defined sustainable development as "development that meets the needs of the present without comprising the ability of future generations to meet their own needs" (United Nations World Commission on Environment and Development, 1987). In a broad sense, the notion of sustainable development may refer to one or more of the following objectives: (1) nurture the natural environment; (2) advance less favoured groups in society or the world; and/or (3) focus on longer-term economic or business success. The definition of fair trade refers particularly to the second objective.

(ii) International trade. The Fair Trade movement sees international trade at the same time as a cause of inequity on a world scale and as a vehicle to alleviate poverty in the South. The underlying concern is that over a longer period the terms of trade for developing nations' trading commodities have consistently fallen, forcing developing countries to export ever larger quantities to earn the same revenues.

Commodities such as bananas, coffee or cotton are essentially homogeneous goods produced in large quantities by many different producers in a large number of countries. The supply and demand of commodities is regulated primarily by international market structures and trends. Individual producers face a multitude of foreign competitors, and are practically unable to influence market outcomes. Today, many commodities are produced by farmers in developing countries with little choice but to act as price-takers.

The decision to pay farmers or their representative organisations in developing countries above-world market prices is an economic intervention that is not without consequences. First, fair trade risks introducing incentives to increase production which will put further pressure on world market prices. If fair trade is ever to cover larger shares of world trade in specific commodities, it could even have the adverse effect of creating or enhancing excess supply, in effect reducing world market prices and potentially damaging other disadvantaged farmers not covered by fair trade schemes. Second, fair trade risks reducing world market pressures and subsidising uncompetitive structures or practices. Third, fair trade requires independent organisations to monitor and certify suppliers, introducing a costly bureaucracy and politics.

Thus, international trade theory points at some potential unintended consequences of fair trade that trade economists and the Fair Trade movement should address in an open-minded way. For instance, trade economists could model or estimate the possible price-distorting effects of fair trade subsidies, while certification institutions could seek to combine developmental and productivity-rated objectives. A failure to address these unresolved issues would be a disservice to the fair trade cause and would leave the movement vulnerable to criticism. 
(iii) Partnership. Fair trade is understood as a trading partnership between the private, public and civil society sector. Recently there has been a rise of public-private partnerships (PPPs), in which private, public, and occasionally civil society sector actors cooperate to realise specific public objectives (Mulder/Van Tulder 2004). The collaboration typically involves a financial commitment of both the private and public sector partners (and if present of the civil society sector partners). Forms of public or civil society sector involvement vary from investment participation, subsidies, tax waivers, through procurement guarantees. In a developmental context, PPPs often appear as public-private development partnerships (PPDPs). A PPDP is a PPP with the objective to contribute to economic development prospects in developing countries (Gruber/Rothenberg 2005).

A key challenge of PPDPs is to identify stakeholders that should be involved, i.e. the relevant and salient stakeholders. It is not always easy to apply the 'Principle of Who and What Really Counts' (Freeman 1994). Mitchell, Agle and Wood (1997) suggest three attributes to identify stakeholder relevance and salience: actors' power, legitimacy, and urgency. However, Jensen (2001) pointed out that stakeholder theory advocates refuse to specify how to make the necessary trade-offs among competing interests. As a result, managers would be left with a theory that makes it impossible to make purposeful decisions: "multiple objectives is no objectives" (Jensen 2001, 10). Put differently, according to Jensen managers can justify any transaction and are hence more likely to serve their own interests if firms pursue multiple objectives. In this article we will evaluate this critique of stakeholder involvement.

A second challenge is to acknowledge that the fair trade definition harbours a potential contradiction. In the long run, international commodity chains will remain competitive only if each actor seeks to maximise its own benefits, which sooner or later will put pressure on other partners. The challenge of managing fair trade international commodity chains is to mediate but not root out withinchain competition.

The above discussion suggests further conceptual development on the notion of fair trade is required in terms of (1) the exact meaning of sustainability, (2) unintended consequences of fair trade schemes, and (3) clarity on the exact meaning of partnership.

\subsection{Commodity Chains}

In the field of development studies it is increasingly acknowledged that international networks play an important role in contemporary development (McFarlane 2006). Thus, a commodity chain may be analysed as an external or strategic network. An external network may be defined as an institutionalised arrangement among distinct but related for-profit and not-for-profit organisations with the purpose to obtain a sustainable competitive advantage (Gulati/Nohria/Zaheer 2000; Sydow/Winkler 1998). ${ }^{1}$ This definition is broader than some definitions

${ }^{1}$ Sustainable competitive advantages may be defined as the creation or existence of re- 
used in the literature but best reflects the reality of multi-stakeholder international commodity chains.

(i) Network configuration and coordination. Studying network configuration helps to identify the relative positions and power of partners within a network, and ultimately the allocation of costs and benefits. For this purpose, the literature has developed the concept of core firm (Ruigrok/Van Tulder 1995) or focal firm (Sydow/Winkler 1998). A core firm occupies a structural hole within a network (Burt 1992) based on superior (technological, production, and/or marketing) knowledge and/or financial capacity. These advantages enable a core firm to influence the network strategy and behaviour of individual network partners. We will show below how a core firm may design and manage an international commodity chain.

Since external networks do not operate on the basis of 'command and control' associated with large firms ('hierarchies'), a variety of formal and informal coordination mechanisms has emerged in order to form and sustain the network and make sure that 'the sum is more than the parts' (Grandori/Soda 1995). In particular, an extensive literature has sought to conceptualise and measure the role of trust within networks. Trust is typically understood as the antithesis of 'control' and may be divided into 'competence trust' and 'intentional trust'. Competence trust refers to the trust one has in a partner's technical, cognitive, organisational and communicative competencies, while intentional trust refers to the trust one has in a partners' intentions towards the relationship, particularly in refraining from opportunism (Klein Woolthuis/Hildebrand/Nooteboom 2005). Both types of trust may help to deal with uncertainty and accept vulnerability (Newell/Swan 2000, 1293). The network literature suggests that trust is a key factor in building and maintaining networks, and that trust may both facilitate and follow from network interaction.

(ii) Supply chain management. There are obvious parallels between commodity chains and the supply chains which are dominant in manufacturing industries ranging from cars to food. Supply chain management refers to the planning and management of all 'primary' activities that are specific to a product, i.e. design and development, supply, production, distribution, marketing and post-sales services, plus 'supporting' activities such as R\&D, human resources and finance (Rieple/Singh 2010). Although extant research in supply chain management "has remained largely anecdotal and theoretically underdeveloped" (Chen/Paulraj/Lado 2004, 505; see also Wacker 2004), research has established key supply chain design and management characteristics that appear to be associated with superior firm performance. These characteristics may be summarised as follows: (1) foster close working relationships with a limited number of suppliers; (2) promote open communication among supply chain partners; and (3) develop a long-term strategic relationship orientation to mutual gains (Chen/Paulraj/Lado 2004, 506). These criteria will be returned to below in assessing emerging organic cotton chain characteristics.

sources that are at the same time valuable, rare, difficult or costly to imitate, and that require a specific organisation to leverage (Barney 1997). 


\subsection{Certification}

A key success factor of fair trade is the establishment of certification institutions (Gilbert/Rasche 2007; Huybrechts 2010). It will be difficult to sustain fair commodity chains without credible certification institutions. Such institutions (1) help persuade consumers to pay cost-plus prices for homogeneous goods over a longer period of time, thus (2) provide planning stability for all actors participating in a given commodity chain, and (3) ultimately facilitate the shift from niche to mass market (Mahé 2010).

Certification institutions have two components: "a set of rules, principles or guidelines (usually in the form of a code of conduct) and a reporting or monitoring mechanism (often a corporate environment report or a 'social audit')." (Gereffi/Garcia-Johnson/Sasser 2001, 57) Today, national or international labels can be found for e.g. retailers, textiles, wood, flowers, food and energy. Labels differ in terms of institutions, criteria and monitoring modus (Stückelberger 2002):

- Private labels are assigned by private institutions (NGOs, companies, branches associations etc.) based on specific commitments and audited with control mechanisms or monitor systems;

- National labelling is similar to the private labelling, yet instead of private institutions governmental or supranational organisations are responsible for the labelling process (e.g. the EU Eco-label);

- Product labels;

- Company labels (popular with retailers);

- Pure quality labels which refer to the primarily technical quality of a product or company;

- Eco- or organic labels denote the eco-quality of one or more production sections or manufacturing methods; the auditing processes may differ in their extent (certain labels take the whole life cycle of a product into account, others only some attributes);

- Social labels denote products or companies which enable better working conditions for the actors of the value chain. Most social labels are based on minimal standards stated by the International Labor Organisation;

- Labels in conversion.

The essence of the labelling process is monitoring standards and implementation. Table 1 presents three dominant monitoring system models. The costs of creating and maintaining certification institutes tend to increase as their scope becomes more encompassing. A key challenge for third-party certification institutions is to prevent inter-NGO strife and agree upon common standards that may be implemented and communicated to consumers. 


\begin{tabular}{|c|c|c|}
\hline Type & Explanation & Example \\
\hline $\begin{array}{l}\text { Company's } \\
\text { own } \\
\text { monitoring }\end{array}$ & $\begin{array}{l}\text { 1. Company formulates own } \\
\text { code/standards } \\
\text { 2. Company sets up and finances } \\
\text { foundation to monitor } \\
\text { 3. Foundation conducts audits at } \\
\text { suppliers, producers, middlemen } \\
\text { 4. Foundation reports back to } \\
\text { company }\end{array}$ & $\begin{array}{l}\text { Swiss retailer } \\
\text { Coop introduced } \\
\text { its naturaline } \\
\text { organic cotton } \\
\text { label in } \\
\text { cooperation with } \\
\text { Remei }\end{array}$ \\
\hline $\begin{array}{l}\text { Independent } \\
\text { tripartite } \\
\text { monitoring }\end{array}$ & $\begin{array}{l}\text { 1. Company and NGO formulate } \\
\text { joint code/standards } \\
2 \text {. An independent monitoring unit } \\
\text { is established, jointly financed by } \\
\text { the company and NGO } \\
\text { 3. Monitoring unit audits } \\
\text { suppliers, producers, middlemen } \\
\text { 4. Monitoring unit reports back to } \\
\text { company and NGO }\end{array}$ & $\begin{array}{l}\text { Chiquita and the } \\
\text { NGO Rainforest } \\
\text { Alliance }\end{array}$ \\
\hline $\begin{array}{l}\text { Independent } \\
\text { standardised } \\
\text { monitoring }\end{array}$ & $\begin{array}{l}\text { 1. Independent standardisation } \\
\text { institution is created that drafts } \\
\text { code/standards } \\
2 \text {. Standardisation institution } \\
\text { accredits certification institution } \\
\text { 3. Certification institution certifies } \\
\text { the company, which reports back } \\
\text { to the certification institution } \\
\text { 4. Certification institution audits } \\
\text { suppliers, producers, middlemen }\end{array}$ & $\begin{array}{l}\text { Max } \\
\text { Havelaar/FLO } \\
\text { (social labelling) } \\
\text { or ECOCERT } \\
\text { (eco labelling) }\end{array}$ \\
\hline
\end{tabular}

Table 1: Labelling: models of monitoring and certification (based on Stückelberger 2002; Ims/Jakobsen 2006). 


\section{The Market for Conventional and Organic Cotton}

Cotton and textile chains connect three different 'worlds' which each have their own logic (De Man 2002):

Agriculture/production. In agriculture, production quality is variable due to e.g. soil and climate conditions. Agriculture is connected to regional and local communities and both production cycles and changes in agriculture often have long lead times.

Textile industry. Textile manufactures, retailers and brands work with standardised, fixed qualities. The very challenge of textile production is to turn variable cotton inputs into standardised products which is done by selecting qualities and mixing. The cotton traders are the important actors in between those two worlds. The textile industry allows for much faster change than agriculture, and is operating on an increasingly global scale.

Consumer market. The emotional world of the consumer market is completely different from the industrial world. Fashion is highly volatile and works with very short time dimensions. Here retail companies and brand owners are the link between the industrial world and the consumers. Their role is to translate the emotionally defined wishes of the consumer into technical concepts for materials and their use in fashion. Retailers and brand owners are often very big and often operate globally.

The three worlds do not have only a different logic, but also 'think in different time periods'. In total, there are some eighteen months between the time a farmer starts planting and the time the retailer puts a finished cotton product in the store. Over this period, cotton production goes through the following processing stages: agricultural production, ginning, spinning, knitting, dyeing, garmenting and retailing. After the ginning process cotton has become a commodity with a number of standard parameters and grades. Spinning, weaving/knitting and clothing production may be done by different business actors or by vertically integrated actors. Over the last decades, many combinations have arisen, e.g. spinners may also be fabric producers, or clothing producers may have their own knitting. At the end of the chain clothing brands and retailers often minimise their involvement in production to design and outsource all or most production steps.

Roughly $78 \%$ of all cotton is produced in only six countries. In 2005, China was the leading producer with 24 per cent of world production, followed by the U.S. (19 per cent), India (16 per cent), Pakistan, Brazil and Uzbekistan. World cotton production and cotton yield per unit area have been steadily increasing, because of the development of high-yielding cotton cultivars, especially cotton hybrids. More than $50 \%$ of the raw cotton ends up in clothing; more than $25 \%$ as home textiles (Kooistra/Termorshuizen 2006).

Because cotton is sensitive to drought, low temperatures and attacks by various insects, cotton is a difficult crop to grow. Across the world fertilisers are used in order to increase crop yields, yet the disadvantages to farmers and the natural environment of using high quantities of fertilisers or pesticides have become increasingly clear. One response to reduce the quantity of pesticides has been 
the introduction of genetically modified cotton (GMC). According to estimates GMC accounted for 28 per cent of world cotton production in 2006 (Organic Exchange 2006; Brookes/Barfoot 2006).

While it has been argued that the introduction of GMC has led to a significant reduction of pesticides, increased cotton yields and higher revenues (Brookes/Barfoot 2006), other research suggests these benefits have been overstated (Wang/Just/Pinstrup-Andersen 2006). Indeed, GMC has become the object of fierce debate. For instance, the International Federation of Organic Agriculture Movements (IFOAM), an organisation with 750 member organizations in 108 countries, has pointed at the risks associated with the release of organisms which have never before existed in nature and which cannot be recalled, a violation of farmers' fundamental property rights following from using property right-protected GMC, and a subsequent threat to farmers' economic independence (IFOAM 2006).

Partly in response to the growth of GMC, critical NGOs, cotton processing and trading firms and retailers have strengthened already existing efforts to promote organic cotton. Based on principles of organic farming, organic cotton seeks to sustain and enhance throughout the commodity chain the health of ecosystems and organisms from the smallest organism in the soil to human beings (Eyhorn/Ratter/Ramakrishnan 2005). In order to verify that cotton is organic and to receive a premium price, cotton production must be recognised as organic by a certifying institution. World production of organic cotton has increased dramatically over the past ten years. By 2005 , organic cotton still only made up some 0.1 per cent of total world cotton production, by 2009 this had increased to 0.76 per cent (Organic Trade Association 2011). Data suggest there has been a shift from developed countries to developing countries (India, Pakistan, Turkey, Israel and to a lesser extent Mali and Burkina Faso). Cotton production in Saheleconomies like Mali has been problematic given its heavy nutrients demands and associated use of inorganic fertilisers and pesticides (Moseley 2005). To such economies, GMC and organic cotton may offer competing alternatives.

Compared to conventional cotton, organic cotton is not yet a commodity. This means that the quality of organic cotton crop is not yet highly standardised (although quality parameters have been established) and sales are mainly based on (long-term) commitments or pre-plant contracting. For instance, (organic) cotton traders or retailers give producers/cooperatives long-term guarantees, so that producers have an incentive to change from conventional to organic production systems despite the fact that the quality of organic cotton will be lower during the conversion process. Thus far, the growth of the organic cotton market is driven by demand, not by supply. Brand-owners such as Wal-Mart, Nike, H\&M and M\&S, as well as leading retailers in e.g. France, Germany and Switzerland, have shown an interest to complement their product ranges with organic cotton products. As demand outpaces supply, prices have gone up and downstream traders, brand-owners and retailers have taken an active interest in the entire organic cotton commodity chains. 


\section{Method and Data}

Research on organic cotton commodity chains has been conducted mostly by agricultural experts and policy analysts (exceptions include Naspetti/Lampkin/ Nicolas/Stolze/Zanoli 2011). As a result, data on organic cotton tends to be partial (in both senses of the word) and often not standardised, and published results often serve a broad range of purposes and stakeholder interests. Moreover, as described above, developments in the growth of organic cotton and in the distribution and marketing of organic cotton-based goods have been rapid after the year 2000. In view of this research environment, a multiple case study design was chosen (Yin 1994). In the research process, a number of steps have been made in order to increase internal validity, construct validity, external validity and reliability (Gibbert/Ruigrok 2010).

The first stage of the project consisted of a multi-theoretical literature review on issues of sustainability, fair trade, international commodity chains, and external networks. The purpose of this review was to derive a research framework and state expected patterns, using different theoretical lenses.

During the second stage of the project, we collected information on organic cotton production projections, retailer strategies on introducing organic cotton products, and organic cotton production projects especially in Mali and Burkina Faso. This project was funded by the Swiss government and Helvetas, a Swiss development-oriented NGO, in cooperation with ICCO, a Dutch NGO, and a consortium of Dutch universities, which gave us access to a wide range of individuals, data and archival reports (such as industry, consultants and government documents). Much of the information we obtained access to was of a technical nature hence we carried out over thirty interviews with stakeholders in the North within different organic cotton chains over a two month period. Interviewees were associated with Swiss and Dutch NGOs, Swiss and Dutch government agencies, as well as with NGOs in Mali and Burkina Faso. In addition, we collected data and carried out interviews on another organic commodity chain, i.e. mangos, in order to obtain a better understanding of the specific dynamics of the organic cotton chain, effectively following a multiple case study design (Yin 1994). All interviews took place face to face, in the absence of project sponsors (with the obvious exception of interviews with the project sponsors themselves). In order to facilitate open communication all interviews were made without the use of a tape recorder. Instead, written notes were made during the interview and the interview report was produced immediately afterwards. Interviewees never saw the transcript of another interviewee. The project sponsors did not have access to the interview transcripts. The impression never emerged that the project sponsors sought to influence the outcomes of the study.

In stage three, we analyzed our data and identified market and production trends in the area of organic cotton to develop three rival organic cotton chain models. These models differ in terms of objectives, chain configuration, coordination mechanisms used, stakeholder roles, business models and labelling strategies, and their competitive dynamics. These three models emerged over the past years and have not previously been described empirically. As a result, 
it was not possible to match these models to previous studies, as suggested by Denzin and Lincoln (1984) and Eisenhardt (1989). Therefore, in a fourth stage of the project, we produced a draft report and discussed our findings in order to obtain feedback and some kind of 'validation' from the participant stakeholders. In order to obtain further feedback we also discussed our findings with members of a research team from the Netherlands-based Expert Centre for Sustainable Business and Development Cooperation (ECSAD) who carried out a simultaneous project investigating commodity chains in a number of African countries.

\section{Three Models of Promoting Organic Cotton}

Over the past twenty years, after the first organic cotton was certified in Turkey in 1989/1990, at least three distinct patterns have crystallised in the promotion of organic cotton, reflecting different network configurations and coordination mechanisms; a different role for key stakeholders; different business models; and ultimately different development philosophies. The three models are summarised in table 2 and discussed below. Each represents empirically observable patterns, however, for the sake of a more conceptual comparison we focus on chain structure, network configuration, coordination mechanisms and business models rather than on the names of the actors per se. The sequence of discussing the three models below reflects their proximity to earlier fair trade experiences in fruits.

Model I: Farmers' development. Model I most closely resembles previous successes obtained in fair trade fruit chains. The key motivator in Model I is poverty alleviation for farmers, and the organic chain structure is made subservient to this key purpose. The production of organic cotton takes place in least developed countries such as Mali and Burkina Faso. Most 'management attention' is paid to the upstream part of the commodity chain, with NGOs providing technical and educational support in the field, and trading firms (if necessary established/controlled by the NGO) guaranteeing to buy pre-defined quantities of produce at pre-defined prices. The commodity chain functions on the basis of the 'Push' principle, according to which one or more Fairtrade firm(s) has/have the responsibility to sell the cotton to retail customers the North. Fairtrade Labelling Organizations International (FLO) provides Fairtrade labelling.

The key advantage of Model I organic cotton chains is that there is no core actor and no locus of decision-making. In this sense Model I chains are the most democratic of all three models. To NGOs in the North, Model I chains offer the opportunity to present their constituencies and donors in the North an uncomplicated storyline of unwavering commitment to poor farmers in the least developed countries. One downside of Model I is that by focusing on the upstream end of the commodity chain, the downstream part gets less attention and may be seen as an add-on. In Model I the mental distance between promoting fair organic cotton production and channelling processed goods to the retailer is very large. Initially this mental distance will hamper market creation efforts, i.e. the shift from niche to mass markets. This problem will disappear once 


\begin{tabular}{|c|c|c|c|}
\hline Typology & $\begin{array}{l}\text { I: Farmers, } \\
\text { development }\end{array}$ & $\begin{array}{l}\text { II: Integrated } \\
\text { chain } \\
\text { development }\end{array}$ & $\begin{array}{l}\text { III: } \\
\text { Hierarchical } \\
\text { network } \\
\text { development }\end{array}$ \\
\hline Vision & $\begin{array}{l}\text { Alleviate } \\
\text { farmers' poverty }\end{array}$ & $\begin{array}{l}\text { Develop } \\
\text { sustainable } \\
\text { commodity chain }\end{array}$ & $\begin{array}{l}\text { Develop } \\
\text { sustainable } \\
\text { commodity } \\
\text { network }\end{array}$ \\
\hline Core actor & No core actor & $\begin{array}{l}\text { NGO-cum- } \\
\text { business }\end{array}$ & Business \\
\hline $\begin{array}{l}\text { View of } \\
\text { farmers }\end{array}$ & $\begin{array}{l}\text { Consistent focus } \\
\text { of } \mathrm{NGO} \text { activities }\end{array}$ & $\begin{array}{l}\text { Will benefit from } \\
\text { well-functioning } \\
\text { commodity chain }\end{array}$ & $\begin{array}{l}\text { Everyone will } \\
\text { benefit from } \\
\text { well-run network }\end{array}$ \\
\hline $\begin{array}{l}\text { Organising } \\
\text { principles }\end{array}$ & $\begin{array}{l}\text { - Promote } \\
\text { supply } \\
\text { bottom-up } \\
\text { - Guarantee } \\
\text { demand by } \\
\text { trading firms }\end{array}$ & $\begin{array}{l}\text { - Long-term } \\
\text { chain } \\
\text { partnerships } \\
\text { - Closer } \\
\text { proximity to } \\
\text { markets increases } \\
\text { chances of } \\
\text { success }\end{array}$ & $\begin{array}{l}\text { - Long-term } \\
\text { network } \\
\text { partnerships } \\
\text { - Strive for } \\
\text { efficiency } \\
\text { - Consumer } \\
\text { demand } \\
\text { determines } \\
\text { supply }\end{array}$ \\
\hline $\begin{array}{l}\text { Push/pull } \\
\text { principle }\end{array}$ & Push & Push \& pull & Pull \\
\hline $\begin{array}{l}\mathrm{NGO} \\
\text { role/activities }\end{array}$ & $\begin{array}{l}\text { - Technical } \\
\text { support, } \\
\text { education } \\
\text { - Establish } \\
\text { trading firm if } \\
\text { necessary } \\
\text { - Certification } \\
\text { - Communicate } \\
\text { vision in public } \\
\text { - Tactical rather } \\
\text { than strategic }\end{array}$ & $\begin{array}{l}\text { - Technical } \\
\text { support, } \\
\text { education } \\
\text { - Facilitate chain } \\
\text { development } \\
\text { - Manage } \\
\text { interfaces } \\
\text { - Lobby } \\
\text { authorities } \\
\text { - Communicate } \\
\text { vision in public } \\
\text { - Certification }\end{array}$ & $\begin{array}{l}\text { - Certification at } \\
\text { most }\end{array}$ \\
\hline
\end{tabular}




\begin{tabular}{|c|c|c|c|}
\hline Typology & $\begin{array}{l}\text { I: Farmers } \\
\text { development }\end{array}$ & $\begin{array}{l}\text { II: Integrated } \\
\text { chain } \\
\text { development }\end{array}$ & $\begin{array}{l}\text { III: } \\
\text { Hierarchical } \\
\text { network } \\
\text { development }\end{array}$ \\
\hline $\begin{array}{l}\text { View of } \\
\text { retailers in } \\
\text { North }\end{array}$ & $\begin{array}{l}\text { Important but } \\
\text { little vision how } \\
\text { to reach }\end{array}$ & $\begin{array}{l}\text { Essential yet } \\
\text { major hurdles to } \\
\text { integrate }\end{array}$ & $\begin{array}{l}\text { Key stakeholder } \\
\text { right from start }\end{array}$ \\
\hline $\begin{array}{l}\text { Decision- } \\
\text { making } \\
\text { hierarchy }\end{array}$ & Low & Medium & High \\
\hline $\begin{array}{l}\text { Formal } \\
\text { coordination } \\
\text { mechanisms }\end{array}$ & $\begin{array}{l}\text { Poorly developed } \\
\text { at level of chain }\end{array}$ & $\begin{array}{l}\text { Heavily utilised } \\
\text { to develop chain }\end{array}$ & $\begin{array}{l}\text { Integral network } \\
\text { management }\end{array}$ \\
\hline Role of trust & Underdeveloped & $\begin{array}{l}\text { Strong and } \\
\text { facilitated by } \\
\text { NGO }\end{array}$ & $\begin{array}{l}\text { Crucial but } \\
\text { skewed in favour } \\
\text { of core firm }\end{array}$ \\
\hline $\begin{array}{l}\text { Role of } \\
\text { government }\end{array}$ & $\begin{array}{l}\bullet(\mathrm{Co}-) \text { Finance } \\
\text { NGOs }\end{array}$ & $\begin{array}{l}\text { - }(\mathrm{Co}-) \text { Finance } \\
\text { - Enhance } \\
\text { legitimacy }\end{array}$ & - None \\
\hline Strength & $\begin{array}{l}\text { - Moral high } \\
\text { ground: choice } \\
\text { for the poorest } \\
\text { people } \\
\text { - Easy sales } \\
\text { pitch to donors } \\
\text { in North }\end{array}$ & $\begin{array}{l}\text { - Long-term } \\
\text { vision } \\
\text { - NGO role } \\
\text { enhances } \\
\text { consumer trust } \\
\text { - Closer } \\
\text { proximity to } \\
\text { markets }\end{array}$ & $\begin{array}{l}\text { - Long-term } \\
\text { vision } \\
\text { - Robust } \\
\text { structure } \\
\text { - Efficient }\end{array}$ \\
\hline Weakness & $\begin{array}{l}\text { - Mental } \\
\text { distance to } \\
\text { markets } \\
\text { - Fails to take } \\
\text { cotton chain } \\
\text { specifics into } \\
\text { account }\end{array}$ & $\begin{array}{l}\text { - Costs difficult } \\
\text { to control } \\
\text { - No control } \\
\text { limits ability to } \\
\text { enforce vision }\end{array}$ & $\begin{array}{l}\text { - Confusing } \\
\text { labelling } \\
\text { - Little } \\
\text { transparency } \\
\text { - Risk of supplier } \\
\text { defection }\end{array}$ \\
\hline
\end{tabular}

Table 2: Three business models to promote organic cotton (source: author). 
mass markets have emerged. From that point on, market forces may encourage Model I actors to optimise their contribution to the overall commodity chain, potentially leading to a well-functioning division of labour.

Model II: Integrated chain development. Model II differs from Model I in that it has sought to take into account the differences in chain complexity between fruit chains on the one hand and cotton chains on the other. In Model II, establishing and nurturing a commodity chain that is economically sustainable and that involves a long-term partnership among network actors is seen as crucial ultimately to alleviate poverty in the South. The key difference with Model I is on the means, not on the ends. In Model II the focus of management attention is the entire commodity chain. Production is located in poor countries such as Mali and Burkina Faso, and contracts are agreed upon in advance between farmers or their cooperatives on the one hand and trading and retail companies on the other hand regarding quantities and price, typically based on NGO involvement and facilitation. FLO provides Fairtrade labelling.

The distinctive characteristic of Model II is the 'integrative' perspective both to commodity chain development and to the multi-stakeholder environment. In Model II, one NGO takes responsibility for generating equity and partnership along the entire commodity chain. Thus, traders and retailers in the North are treated as important stakeholders just like poor farmers in the South. To development-oriented NGOs based in the North, Model II offers a complex story which may be more difficult to communicate to donors and governments who act as co-financiers. However, these disadvantages may be off-set by visible results. An important challenge in Model II is to link up with strong retail partners that are truly keen to expand their range of organic cotton-based products. Thus compared with Model I, Model II has a higher likelihood to facilitate the shift from niche to mass markets. NGO coordination and stakeholder commitment potentially help to reduce transaction costs and facilitate competence and intentional trust (Klein/Woolthuis/Hildebrand/Nooteboom 2005). In an industry working with an 18-month cycle, downstream actors' ability to plan garmenting, distribution and marketing long in advance may prove to be a crucial benefit to increase volumes and shift to mass markets.

Model III: Hierarchical network development. Model III takes the logic of integrated chain development to the extreme. In Model III, the locus of decision-making lies unambiguously in the North. Inspired by the Toyota Production System (Womack/Jones/Roos 1990), a commercial firm acts as core firm or 'spider in the web'. Large retailers and brand-owners express anticipated market trends and consumer demands in the North 18 months ahead. Along the 'pull' principle, these demands are translated into distribution and production requirements, and ultimately into implications for farmers in the South (based e.g. in Tanzania). Just like in Models I and II, farmers obtain guarantees that specific quantities will be bought at given prices. Unlike Models I and II, however, certification takes place by a foundation controlled by the company itself, instead of FLO, and the retailer developed its own label. The official reason for this is that FLO labelling is too bureaucratic and expensive. 
The definitive characteristic of Model III is the network management approach. Intra-network coordination mechanisms are most developed of all three models, though these tend to be formal and hierarchical. Due to the close links with retailers in the North, Model III also has the potential to create mass markets. Model III can be a profit-making venture (although a large share of earnings needs to be spent on marketing in order to reach or educate mass-market consumers). However, just like in the case of the Toyota Production System, Model III partners are effectively caught in a controlling-cum-nurturing system at the same time (Ruigrok/Tate 1996). Thus, a key criterion for funds transferred to the South is that these funds benefit local farmers as well as the entire network. Proceeds are channelled to a foundation sponsoring measures in the South e.g. to improve productivity, safety, worker satisfaction, or job security.

Model III emerged in the 1990s and partly inspired the rise of models II and I. However, once established, Model III networks are difficult to replicate for a number of reasons:

- Developing a stable network of reliable partners that trust each other may take 8-10 years.

- Knowledge of individual stages of the chain does not suffice for replication: what is needed is an understanding of the entire network and its interfaces.

- Downstream, a major retailer needs to be willing and able to stand up and market organic cotton products credibly and over a longer period of time.

- Infrastructure quality and access to efficient and reliable maritime transportation are essential yet time-consuming to develop.

\section{Discussion}

The three models of promoting fair and organic cotton identified in this article differ in terms of objectives, chain configuration, coordination mechanisms used, stakeholder roles, business models and labelling strategies.

First, Model I showed that just like commercial companies, developmentoriented NGOs may become victims of a 'dominant logic' (Prahalad/Bettis 1986), i.e. mental models and value sets that reflect past successes rather than a thorough analysis of industry structures and stakeholder configuration. Model I has built on previous strengths and market conditions which are not yet prevalent for organic cotton. At the same time, however, Model II shows that NGOs may recognise such failures, learn from examples developed by commercial firms and adapt their approaches. Thus, Models II and III are more likely to help create a mass market. However, once mass markets have emerged, Model I may actually become the more promising model.

Second, moving from Model I to III, commodity chain structures become more integrated, more market-oriented, and tilted towards stakeholder interests 


\begin{tabular}{|c|c|c|}
\hline $\begin{array}{l}\text { Coordination } \\
\text { mechanism }\end{array}$ & Model II & Model III \\
\hline Communication & $\begin{array}{l}\text { Frequent, } \\
\text { coordination purpose }\end{array}$ & Extensive, controlled \\
\hline $\begin{array}{l}\text { Decision and } \\
\text { negotiation } \\
\text { mechanisms }\end{array}$ & More democratic & Top-down \\
\hline $\begin{array}{l}\text { Social coordination } \\
\text { mechanisms }\end{array}$ & $\begin{array}{l}\text { Limited ('different } \\
\text { worlds') }\end{array}$ & More developed \\
\hline $\begin{array}{l}\text { Integration } \\
\text { mechanisms }\end{array}$ & Limited & Limited \\
\hline $\begin{array}{l}\text { Common staff } \\
\text { mechanisms }\end{array}$ & Limited & Probably limited \\
\hline $\begin{array}{l}\text { Planning and control } \\
\text { system mechanisms }\end{array}$ & Emerging & Relatively advanced \\
\hline $\begin{array}{l}\text { Incentive system } \\
\text { mechanisms }\end{array}$ & $\begin{array}{l}\text { Limited due to } \\
\text { guaranteed payments }\end{array}$ & $\begin{array}{l}\text { Limited due to } \\
\text { guaranteed payments }\end{array}$ \\
\hline $\begin{array}{l}\text { Selection system } \\
\text { mechanisms }\end{array}$ & Democratic & $\begin{array}{l}\text { Top-down, partly } \\
\text { performance based }\end{array}$ \\
\hline $\begin{array}{l}\text { Information system } \\
\text { mechanisms }\end{array}$ & Embryonic & More advanced \\
\hline $\begin{array}{l}\text { Public support and } \\
\text { infrastructure } \\
\text { mechanisms }\end{array}$ & Elaborate & Limited \\
\hline Trust & $\begin{array}{l}\text { Competence and } \\
\text { intentional trust high } \\
\text { in North, medium in } \\
\text { South }\end{array}$ & $\begin{array}{l}\text { Competence and } \\
\text { intentional trust high } \\
\text { in North, lower but } \\
\text { significant in South }\end{array}$ \\
\hline
\end{tabular}

Table 3: Network coordination mechanisms in model II and III (based on Grandori/Soda 1995; Klein Woolthuis/Hildebrand/Nooteboom 2005). 
in the North. A stronger business orientation reduces the risk of subsidising excess and/or uncompetitive production. While Model I functions without a focal actor, such actors play a key role in Models II and III, providing key integration mechanisms which are essential for network success. Table 3 shows interesting similarities and differences between Model II and III. Some coordination mechanisms more typically associated with sophisticated industrial production networks are less developed in both models (e.g. common staff mechanisms). Coordination mechanisms used in Model II tend to be more democratic and based on equity among all stakeholders, whereas in Model III the stronger business orientation is associated with more hierarchical and top-down mechanisms.

Third, the commodity chain configuration of the three models makes it difficult to reach consensus on the use of one dominant 'fair' and/or 'organic' label. While Models I and II comply with FLO certification procedures, financial concerns led the core firm in Model III to decline such inspections. (Instead, certification resembles the pattern described in table 1, first column.) It may be tempting to reject Model III for its lack of democracy and its independent labelling strategy. However, partnership is not the same as partner equality. Credits should be given to an entrepreneur who developed and implemented a vision to promote organic cotton in a sustainable and commercial manner before NGOs entered the field. Furthermore, cost control is an integral factor of any commercial venture, and there is a distinct risk for certification to become ever more cumbersome and costly. Cost control may be the best thing certification institutions can do to promote their standards.

Finally, the three models have each developed their own competitive dynamics, although participants obviously observe trends in the other models. In that sense our analysis reflects a snapshot of the 2006 situation. For this reason, we did not discuss cost structures and profitability data (which are partly available to the researchers). Today's cost structures and profitability ratios reflect longer-term investment strategies in a rapidly evolving market instead of fully crystallised business models.

\section{Conclusions}

As the market for 'ethical products' is expanding, new questions to be addressed include the trajectories that private, public and civil society sector should embark upon in order to affect a shift from niche to mass markets, and the certification strategies that ethical producers should adopt in order to reduce potential consumer confusion on products' 'fair' and/or 'organic' traits. Looking at the case of fair organic cotton, the article argued that these two questions are both affected at least partly by configurations and interests currently emerging along the cotton commodity chains.

Different organic cotton chain/network configurations and interfaces are associated with specific stakeholder positions and interests, and ultimately development philosophies. There is not one inherently superior strategy in promoting organic cotton, and rival chain structures may impede a rapid agreement upon 
common labelling on organic cotton. The case of organic cotton shows the difficulties in agreeing upon common labelling, suggesting that consumers may continue to be confronted with confusing labels also in the future.

Finally, the article suggests that stakeholder involvement may not necessarily only be a cost factor as suggested by stakeholder theory criticasters (Jensen 2001). To private sector actors the costs of deviating from their 'ideal' strategies or behaviours may indeed be substantial. However, this article shows that multi-stakeholder networks may also serve to create new markets or market segmentation with the potential of new revenues. Such new markets have been the very reason why companies were interested in joining or setting up complex multi-stakeholder networks in the first place.

\section{Bibliography}

Barney, J. B. (1997), Gaining and Sustaining Competitive Advantage, Reading

Brookes, G./P. Barfoot (2006), GM Crops: The First Ten Years-Global Socio-Economic and Environmental Impacts, ISAAA Brief No. 36, Ithaca

United Nations World Commission on Environment and Development (1987), Our Common Future, Oxford (also known as the Brundtland Report)

Burt, R. S. (1992), Structural Holes: The Social Structure of Competition, Cambridge/ MA

Chen, I. J./A. Paulraj/A. A. Lado (2004), Strategic Purchasing, Supply Management and Firm Performance, in: Journal of Operations Management 22, 505-523

Crane, A. (2001), Unpacking the Ethical Product, in: Journal of Business Ethics $30(4), 361-373$

De Man, R. (2002), The Global Cotton and Textile Chain: Substance Flows, Actors and Co-operation for Sustainability. A Study in the Framework of WWF's Freshwater and Cotton Programme, Unpublished Final Report, Leiden

Denzin, N. K./Y. S. Lincoln (1994), Handbook of Qualitative Research, London

Didier, T./S. Lucie (2008), Measuring Consumer's Willingness to Pay for Organic and Fair Trade Products, in: International Journal of Consumer Studies 32, 479-490

Eisenhardt, K. M. (1989), Building Theories from Case Study Research, in: Academy of Management Review 14(4), 532-550

European Fair Trade Association (2011), URL: http://www.european-fair-tradeassociation.org/observatory/index.php/en/fairtrade [29.07.2011]

Eyhorn, F./S. C. Ratter/M. Ramakrishnan (2005), Organic Cotton Crop Guide, Research Institute of Organic Agriculture FiBL, Switzerland

Freeman, R. E. (1994), The Politics of Stakeholder Theory: Some Future Directions, in: Business Ethics Quarterly 4, 409-421

Garriga, E./D. Melé (2004), Corporate Social Responsibility Theories: Mapping the Territory, in: Journal of Business Ethics 53(1-2), 51-71

Gereffi, G./R. Garcia-Johnson/E. Sasser (2001), The NGO-Industrial Complex, in: Foreign Policy, July-August, 56-65

Gibbert, M./W. Ruigrok (2010), The 'What' and 'How' of Case Study Rigor: Three Strategies Based on Published Research, in: Organizational Research Methods 13(4), 710-737

Gilbert, D. U./A. Rasche (2007), Opportunities and Problems of Standardized Ethics Initiatives: A Stakeholder Theory Perspective, in: Journal of Business Ethics 82, $755-773$ 
Grandori, A./G. Soda (1995), Inter-Firm Networks: Antecedents, Mechanisms and Forms, in: Organization Studies 16(2), 183-214

Griffiths, P. (2011), Ethical Objections to Fairtrade, in: Journal of Business Ethics, published on-line

Gruber, W./D. Rothenberg (2005), Öffentlich-private Partnerschaften: Ein Ansatz zur Verbesserung der Infrastruktur, in: Öffentlich-private Partnerschaften und internationale Entwicklungshilfezusammenarbeit. Schweizerisches Jahrbuch für Entwicklungshilfe, Band 42, Nr. 2, Institut universitaire d'études du developpement, $79-96$

Gulati, R./N. Nohria/A. Zaheer (2000), Strategic Networks, in: Strategic Management Journal 21, 203-215

Hira, A./J. Ferrie (2006), Fair Trade: Three Key Challenges for Reaching the Mainstream, in: Journal of Business Ethics 63, 107-118

Huybrechts, B. (2010), Fair Trade Organizations in Belgium, in: Journal of Business Ethics 92, 217-240

IFOAM (1996), International Organic Standard, URL: http://www.ifoam.org

Ims, K. J./O. D. Jakobsen (2006), Cooperation and Competition in the Context of Organic and Mechanistic Worldviews: A Theoretical and Case Based Discussion, in: Journal of Business Ethics 66, 19-32

Jensen, M. C. (2001), Value Maximization, Stakeholder Theory, and the Corporate Objective Function, in: Journal of Applied Corporate Finance 14(3), 8-21

Klein Woolthuis, R./B. Hildebrand/B. Nooteboom (2005), Trust, Contract and Relationship Development, in: Organization Studies 26(6), 813-840

Kooistra, K./A. Termorshuizen (2006), The Sustainability of Cotton: Consequences for Man and Environment, Report 233 (Science Shop Wageningen)

Loureiro, M. L./S. Lotade (2005), Do Fair Trade and Eco-Labels in Coffee Wake Up the Consumer Conscience?, in: Ecological Economics 53, 129-138

Mahé, T. (2010), Are Stated Preferences Confirmed by Purchasing Behaviours? The Case of Fair Trade-Certified Bananas in Switzerland, in: Journal of Business Ethics 92, 301-315

McFarlane, C. (2006), Transnational Development Networks: Bringing Development and Postcolonial Approaches into Dialogue, in: The Geographical Journal 172(1), $35-49$

Meier, T. (2004), Von der Nische in den Massenmarkt: Unternehmensethik und Nichtregierungsorganisationen, in: Ruh, H./E. Leisinger (eds.), Ethik im Management. Ethik und Erfolg verbünden sich, Zürich, 299-308

Mitchell, R. K./B. R. Agle/D. J. Wood (1997), Toward a Theory of Stakeholder Identification and Salience: Defining the Principle of Who and What Really Counts, in: Academy of Management Journal 22, 853-886

Moseley, W. G. (2005), Global Cotton and Local Environmental Management: The Political Ecology of Rich and Poor Small-Hold Farmers in Southern Mali, in: The Geographical Journal 171(1), 36-55

Mulder, A./R. Van Tulder (2004), PPPs: Beneficial to Whom?, in: European Business Forum 18, 24-26

Naspetti, S./N. Lampkin/P. Nicolas/M. Stolze/R. Zanoli (2011), Organic Supply Chain Collaboration: A Case Study in Eight EU Countries, in: Journal of Food Products Marketing 17, 141-162

Newell, S./J. Swan (2000), Trust and Inter-Organizational Networking, in: Human Relations 53, 1287-1328 
Organic Trade Association (2011), URL: http://www.ota.com/organic/mt/organic cotton.html [29.07.2011]

Porret, S./C. Chambol (2007), Fair Trade Labelling: Inside or Outside Supermarkets?, in: Journal of Agricultural $\&$ Food Industrial Production 5(1), 1-29

Prahalad, C. K./R. A. Bettis (1986), The Dominant Logic: A New Linkage between Diversity and Performance, in: Strategic Management Journal 7, 485-501

Rieple, A./R. Singh (2010), A Value Chain Analysis of the Organic Cotton Industry: The Case of UK Retailers and Indian Suppliers, in: Ecological Economics 69, 22922302

Ruigrok, W./R. Van Tulder (1995), The Logic of International Restructuring, London-New York

- /J. J. Tate (1996), Public Testing and Research Centres in Japan: Control and Nurturing of Small and Medium-sized Enterprises in the Automobile Industry, in: Technology Analysis and Strategic Management 8(4), 381-406

Stiglitz, J. E./A. E. Charlton (2005), Fair Trade for All: How Trade Can Promote Development, Oxford

Stückelberger, C. (2002), Ethik der Etiketten-Die entwicklungspolitische Bedeutung von Labels und Verhaltenskodizes im Welthandel, in: Ulrich, P./B. Waxenberger (eds.), Standards und Labels II, Institut für Wirtschaftsethik der Universität St. Gallen, St. Gallen, 1-21

Sydow, J./A. Winkler (1998), Organizing and Evaluating Interfirm Networks: A Structurationist Perspective on Network Processes and Effectiveness, in: Organization Science 9, 265-284

Valkila, J. (2009), Fair Trade Organic Coffee Production in Nicaragua: Sustainable Development or a Poverty Trap?, in: Ecological Economics 68, 3018-3025

Wang, S. H./D. R. Just/P. Pinstrup-Andersen (2006), Damage from Secondary Pest and the Need for Refuge in China, in: Just, D. R./J. M. Alston/D. Zilberman (eds.), Regulating Agricultural Biotechnology: Economics and Policy, New York, 625-637

Wacker, J. (2004), A Theory of Formal Conceptual Definitions: Developing Theorybuilding Measurement Instruments, in: Journal of Operations Management 22, 629-650

Womack, J./T. Jones/D. Roos (1990), The Machine that Changed the World, New York

Yin, R. K. (1994), Case Study Research: Design and Methods, London 
